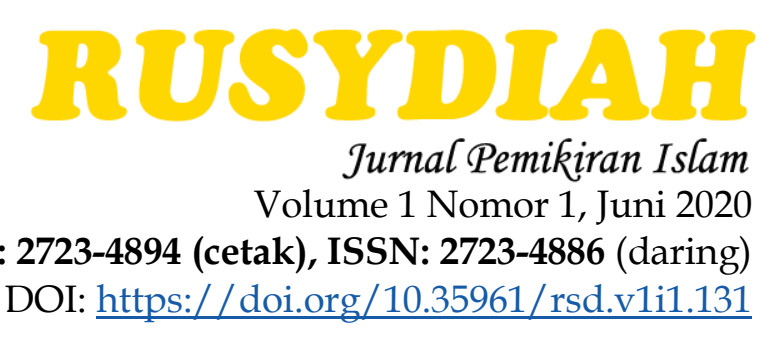

\title{
PERAN TEORI QIRA'AT DALAM MEMAHAMI AYAT-AYAT RELASI GENDER
}

\author{
Parluhutan Siregar \\ UIN Sultan Syarif Kasim Riau \\ Email: Cendikia26@gmail.com
}

\begin{abstract}
Abstrak
Al-Qur'an diturunkan untuk mengubah bias hubungan gender. Sehubungan dengan ini, perlu untuk membiarkan ayat-ayat al-Qur'an berbicara tentang gender itu sendiri dengan menggunakan varian bacaan (Qira'at) dari Al-Qur'an. Makalah ini bertujuan untuk membangun argumen betapa pentingnya qiraat untuk memahami ayat-ayat yang berbicara tentang gender. Sebagai contoh, ini akan menganalisis QS. Al-Nisa '(4): 19. Ini menyimpulkan bahwa varian bacaan (qira'at) berkontribusi untuk memahami Quran secara tematis dan kontekstual. Kedua, menggunakan qira'at di QS. Al-Nisa '(4): 19, kami memahami bagaimana memposisikan para wanita dengan lebih hormat.
\end{abstract}

Kata kunci: Qira'at; gender; tematik-kontekstual.

\begin{abstract}
Al-Qur'an was sent down to transform the bias gender relation. In relation to this, it is necessary to let the Quranic verses to talk about gender itself by using the variant reading (Qira'at) of the AlQur'an. This paper aims to built the argument how important the qira'at is to understand the verses talking about gender. For example, this will analyze the Q.S. Al-Nisa' (4): 19. This concludes that variant readings (qira'at) contributes to understand the Quran thematically and contextually. Second, using the qira'at in Q.S. Al-Nisa' (4): 19, we understand how to position the women more respectfully.
\end{abstract}

Keywords: Qira'at; gender; thematic-contextual. 


\section{PENDAHULUAN}

Penafsiran tidak terlepas dari bias ideologi sang penafsir. Konstruk sosial dan budaya di mana penafsir hidup turut membentuk hasil penafsiran ketika menafsiran al-Qur'an. Tidak terkecuali budaya patriarkal. Budaya patriarkal adalah sebuah budaya yang mengunggulkan posisi laki-laki di atas perempuan. Ketika menafsiran al-Qur'an para penafsir yang hidup pada masa tersebut, jika tidak memiliki kesadaran akan keterpengaruhan, maka produk penafsirannya sangat mungkin mengandung bias gender.

Al-Qur'an sendiri sejak pertama turun sangat memperjuangkan keadilan gender. Al-Qur'anmelakukan transformasi dan reformasi untuk menghapuskan bias dalam keadilan gender. Hal ini dapat dilihat dari usaha al-Qur'an yang menyinggung persoalan rumah tangga, perkawinan, warisan dan lain-lain. Oleh karenanya, al-Qur'an pada masa sekarang harus tetap dibiarkan untuk menyuarakan keadilan gender dengan memberikan ruang kepada dirinya. Untuk itu, sebagai upaya memahami semangat al-Qur'an dalam menghapuskan ketimpangan gender pada masa ia diturunkan, seorang penafsir harus mempertimbangkan ragam qira'atuntuk kemudian dikontekstualisasikan pada masa sekarang. Qira'at dan al-Qur'an tidak dapat dipisahkan antara satu dengan lainnya.

Posisi ragam qira'at dalam sebuah penafsiran sering dijadikan bahan untuk menafsiran sebuah ayat. Dalam tafsir bercorak fiqih misalnya, qira'at kerap kali mewarnai hasil olah pemikiran para penafsir. Qira'at sendiri merupakan ragam bacaan al-Qur'an yang telah dipraktekkan oleh Nabi maupun para Sahabat.

Berangkat dari latar belakang di atas, tulisan ini secara spesifik akan menawarkan ragam qira'at dalam penafsiran ayat relasi gender. Oleh karenanya, rumusan masalah yang akan dijawab dalam makalah ini ada dua. Pertama, bagaimana peran ragam qira'atdalam memahami ayat al-Qur'an. Kedua, bagaimana penafsiran ayat-ayat relasi gender dengan menggunakan ragam qira'at.

\section{HASIL DAN PEMBAHASAN}

\section{A.Sumbangsih Ragam Qira'at dalam Kajian Tematik-Kontekstual}

\section{Qira'at adalah wahyu}

Selama ini, sebagian penafsir memposisikan qira'at sebagai salah satu sumber dalam menafsirkan ayat al-Qur'an. Hal tersebut dapat dilihat dalam kitab-kitab tafsir bercorak fiqih yang menggunakan ragam qira'at untuk 
mengoksplorasi implikasi hukum dari keragaman qira'at terhadap ayat tersebut.

Al-Qur'an adalah kalam Tuhan yang diturunkan kepada Nabi Muhammad secara mutawatir. Sedangkan qira'at adalah cara baca atau pengucapan. Walaupun kedua istilah ini terkesan berbeda, namun pada hakikatnya antara keduanya seperti dua sisi mata koin yang tak dapat dipisahkan. Al-Qur'an tanpa qira'at tidak mungkin menjadi bacaan. Ini berarti qira'at pada dasarnya adalah wahyu sama dengan al-Qur'an itu sendiri. Ragam qira'at diturunkan kepada Nabi. Qira'at yang berderajat mutawatir adalah al-Qur'an, sedangkan yang tidak sampai kepada derajat mutawatir, tidak termasuk kategori qira'at maupun al-Qur'an. Karenanya, dalam menafsirkan al-Qur'an, qira'at bukan lagi harus diposisikan sebagai sumber sekunder, tetapi menjadi sumber utama atau bahkan objek penafsiran itu sendiri.

\section{Tematik}

Salah satu metode penafsiran yang kita kenal adalah metode tematik atau maudu'i. Metode ini berangkat dari al-Qur'an yufassiru ba'duhu ba'dan. Artinya, metode tematik mengarah pada tema tertentu kemudian mencari pandangan al-Qur'an mengenai tema tersebut dengan cara menghimpun semua ayat yang membicarakannya, menganalisis, dan memahami ayat demi ayat. ${ }^{1}$ Metode ini, menurut Jasser Auda, selangkah lebih maju ke arah penafsiran al-Qur'an yang lebih mempertimbangkan faktor maqasid (purposeful). Metode memahami al-Qur'an dengan tematik, prinsip-prisip dan nilai yang lebih tinggi berangkat dari anggapan bahwa al-Qur'an adalah keseluruhan yang menyatu. ${ }^{2}$

Agak berbeda dengan di atas, kajian tematik dalam hal ini adalah bagaimana keragaman qira'at dalam satu ayat digunakan untuk melihat pesan ayat tersebut. Keragaman qira'at adalah wahyu. Karenanya, keragaman ini perlu dilihat untuk menentukan pesan umum yang yang ingin disampaikan ayat tersebut dari berbagai bacaan yang telah dilegalkan oleh Nabi. Ketika qira'at tersebut terverifikasi berasal dari Nabi, maka qira'at tersebut adalah bagian dari al-Qur'an sendiri. Maka memahami ayat dengan

\footnotetext{
${ }^{1}$ Muhammad Quraish Shibab, Kaidah Tafsir (Tangerang: Lentera Hati, 2013), h. 385.

2 Jasser Auda, Maqasid al-Syariah as Philosophy of Islamic Law: A Systems Approach (London: The International Institute of Islamic Thought, 2007), h. 132.
} 
menggunakan ragam qira'at yang meliputinya adalah bagian dari usaha memberikan ruang kepada al-Qur'an untuk berbicara dengan sendirinya.

Sebenarnya gagasan ini bukan hal baru, sebab praktik penafsiran dengan menggunakan qira'at telah diaplikasikan oleh para sahabat. Keragaman qira'at, sebagaimana yang diungkap oleh Abdul Mustaqim, telah menjadi salah satu sumber penafsiran di era sahabat. Qira'at dengan qira'at yang lain bisa saling memperjelas kandungan ayat. ${ }^{3}$

Lantas tawaran apa yang bisa dikembangkan dari penjelasan di atas? Penafsiran dengan mempertimbangkan berbagai qira'at akan mampu memberikan pemahaman yang lebih komprehensif. Jika beberapa penafsir masih memposisikan qira'at adalah pilihan; mana yang lebih tepat dan sesuai, maka kajian tematik ini memposisikan ragam qira'at dalam satu ayat sebagai satu kesatuan yang saling berhubungan (wholeness). Kesemua qira'at yang muncul dalam lingkup sebuah ayat harus menjadi pertimbangan untuk menarik signifikansi ayat dari berbagai qira'at tersebut.

\section{Kontekstual}

Bagi sebagian orang, kemunculan ragam qira'at masih dianggap sebatas media untuk memberikan kemudahan dalam pengucapan al-Qur'an bagi bangsa Arab dulu. Dasar dari pandangan ini adalah hadis riwayat 'Ubaid bin Ka'ab yang menyatakan Nabi memohon sampai empat kali agar umatnya diberi kemudahan dalam membaca al-Qur'an. Kemudian Jibril menyampaikan untuk membaca al-Qur'andengan tujuh huruf dan huruf manapun yang dibaca adalah benar. Hadis-hadis ini diriwayatkan dalam Sahih Muslim no. 1943, Sunan Abu Daud no. 1480, Sunan al-Nasa'i no. 939, Musnad Ahmad no. 21210, 21214.

Selain itu terdapat hadis-hadis yang menceritakan Jibril mendatangi Nabi Muhammad. Nabi kemudian mengatakan bahwa saya diutus kepada umat yang 'ummi. Di antara mereka ada orang tua dan orang lemah yang belum pernah membaca kitab sekalipun. Kemudian Jibril mengatakan sesungguhnya al-Qur'an diturunkan dengan tujuh huruf. Hadis-hadis ini terdapat dalam Sunan al-Tirmizi no. 2944, Musnad Ahmad no. 21242, 23446 dan

${ }^{3}$ Abdul Mustaqim, Dinamika Sejarah Tafsir Al-Qur'an: Studi Aliran-Aliran Tafsir dari Periode Klasik, Pertengahan hingga Modern-Kontemporer (Yogyakarta: Adab Press, 2012), h. 61. 
23494. Pada hadis lain, Nabi menyatakan di antara umatnya ada orang ummi, anak-anak dan tua renta yang belum pernah membaca kitab sebelumnya. ${ }^{4}$ Beragam hadis di atas menunjukkan bahwa fleksibilitas dalam bacaan sab'ah ahruf bertujuan untuk memberi kemudahan.

Abdullah Saeed memberikan penjelasan bahwa fenomena fleksibilitas dalam bacaan al-Qur'an adalah lampu hijau untuk mendekati pemahaman al-Qur'an dengan berbagai cara yang berbeda. Nabi melegalkan perbedaan pengucapan tentu agar sahabat dan umat Islam pada waktu itu mudah dalam membaca al-Qur'an. Oleh karenanya, bisa saja hikmah dibalik fenomena itu ditarik dalam ranah interpretasi al-Qur'an bahwa al-Qur'an bisa saja didekati dengan berbagai pendekatan untuk memudahkan dalam memahami al-Qur'an pada konteks kekinian. ${ }^{5}$ Penjelasan Saeed di atas mendukung pemahaman kontekstual ayat dengan penggunaan ragam qira'atnya.

Mendudukkan ragam qira'at pada posisi ini, bukan hanya menjadi alternatif dalam memahami ayat al-Qur'an secara kontekstual, tetapi juga berusaha menunjukkan bahwa fenomena fleksibilitas qira'at tidak hanya diperuntukkan bagi bangsa Arab. Adanya fleksibilitas qira'at tersebut memiliki fungsi dan manfaat bagi bangsa non-Arab yang tidak bermasalah dalam persoalan kesulitan pengucapan. Bangsa non-Arab tetap dapat menggunakan ragam qira'at dalam memahami ayat al-Qur'an sesuai konteksnya masing-masing. Dengan begitu, ragam qira'at bukan hanya merespon bangsa Arab, tetapi non-Arab pun juga mendapat perhatian dari fenomena fleksibilitas bacaan al-Qur'an.

\section{B. Persoalan Gender dalam Islam}

Pertama kali perlu dibedakan pengertian dari "seks" dan "gender". Terma "seks" secara umum digunakan untuk mengidentifikasi perbedaan lakilaki dan perempuan dari segi atonomi biologi. Makanya dalam kamus

${ }^{4}$ Athaillah, Sejarah Al-Qur'an: Verifikasi tentang Otentisitas Al-Qur'an(Yogyakarta: Pustaka Pelajar, 2010), h. 176.

${ }^{5}$ Abdullah Saeed, Interpreting the Quran towards a Contemporary Approach (New York: Routledge, 2006), h. 69-76. 
Indonesia seks diartikan dengan jenis kelamin, karena lebih banyak berkonsentrasi pada aspek biologi seseorang, meliputi perbedaan komposisi kimia dan hormon dalam tubuh, anatomi fisik, reproduksi, dan karakteristik biologis lainnya. ${ }^{6}$

Adapun istilah "gender" bisa diartikan sebagai interpretasi mental dan kultural terhadap perbedaan kelamin yakni laki-laki dan perempuan. Gender dipergunakan untuk menunjukkan pembagian kerja yang dianggap tepat bagi laki-laki dan perempuan. Artinya gender sebagai konsep yang digunakan untuk mengidentifikasi perbedaan laki-laki dan perempuan dilihat dari pengaruh sosial budaya. Pengertian ini menunjukkan bahwa gender adalah suatu bentuk rekayasa masyarakat (social constructions), bukannya sesuatu yang bersifat kodrati.7 Jadi istilah seks mengacu kepada sifat biologis, sedangkan gender merupakan persepsi dan harapan-harapan bersifat kultural yang seharusnya kepada laki-laki dan perempuan. ${ }^{8}$

Gerakan feminisme lebih kepada aspek gender, yaitu kedudukan perempuan pada wilayah sosial kultural. Aliran feminisme memandang perbedaan gender telah melahirkan ketidakadilan baik berupa marginalisasi, ${ }^{9}$ stereotipe ${ }^{10}$ subordinasi, $^{11}$ kekerasan ${ }^{12}$ dan beban kerja bagi perempuan. ${ }^{13}$ Sebab

${ }^{6}$ Syarif Hidayatullah, Teologi Feminisme Islam (Yogyakarta: Pustaka Pelajar, 2010), h. 9-10.

${ }^{7}$ Ibid., h. 9.

8 Peter Connolly (ed.), Aneka Pendekatan Studi Agama terj. Imam Khoiri (Yogyakarta: Lkis, 2011), h. 65.

${ }_{9}$ Perbedaan gender menyebabkan perempuan termarginalkan. Marginalisasi perempuan tidak hanya terjadi di tempat kerja, tetapi juga dalam rumah tangga, masyarakat atau kultur dan bahkan negara. Contoh akibatnya perempuan semakin terbatas dalam gerak ekonominya karena pembatasan bahwa perempuan hanya bekerja diwilayah domestik. Bahkan beberapa suku di Indonesia tidak memberikan warisan kepada perempuan. Lihat Mansoer Fakih, Analisis Gender dan Transformasi Sosial..., h. 13.

10 Stereotype adalah pelabelan atau penandaan. Perempuan menjadi korban ketidakadilan karena adanya pelabelan (stereotipe) dalam masyarakat. Seperti perempun diasumsikan bersolek, sehingga setiap ada pelecehan seksual di kaitkan dengan stereotipe ini. Perempuan tugasnya melayani laki-laki sehingga wajar pendidikan perempuan dinomorduakan. Lihat Mansoer Fakih, Analisis Gender dan Transformasi Sosial..., h. 16.

${ }^{11}$ Subordinasi perempuan adalah sikap yang menempatkan perempuan pada posisi yang tidak penting. Anggapan ini berangkat dari asumsi bahwa perempuan itu irasional atau emosional sehingga tidak bisa tampil sebagai pemimpin. Lihat Mansoer Fakih, Analisis Gender dan Transformasi Sosial ..., h. 15.

12 Kekerasan gender disebabkan ketidaksetaraan kekuatan yang ada dalam masyarakat. Kekerasan gender bisa berupa pemerkosaan perempuan atau dalam perkawinan, tindakan pemukulan dalam rumah tangga, dalam pornografi dan sebagainya. Lihat Mansoer Fakih, Analisis Gender dan Transformasi Sosial..., h. 17. 
sifat gender adalah sifat yang bisa diubah dan ditukar dan dipengaruhi oleh konstruk sosial. Sifat gender inilah yang ingin diperjuangkan agar baik laki-laki maupun perempuan tidak menjadi korban dalam konstruk gender.

\section{Nabi seorang feminis}

Feminisme diawali oleh persepsi tentang ketimpangan posisi perempuan dibandingkan laki-laki di masyarakat. Dari ketimpangan ini kemudian muncul berbagai upaya untuk menemukan formula untuk menyatarakan perempuan dan laki-laki dalam segala bidang sesuai dengan potensi yang dimiliki sebagai umat manusia. Upaya tersebut kemudian dikenal dengan gerakan feminis. ${ }^{14}$

Al-Qur'an sebagai rujukan pertama pada dasarnya berusaha memposisikan laki-laki dan perempuan secara adil. Kedudukan perempuan seperti yang digambarkan dalam al-Qur'an merupakan suatu peningkatan nyata dari keadaan yang berlangsung sebelumnya di Arabia pra-Islam. ${ }^{15}$ Bahkan, sesuatu yang tidak bisa dipungkiri, salah satu kunci sukses dakwah Nabi dalam melakukan perubahan-perubahan dalam masyarakat Arab, adalah karena ajaran-ajaran yang dibawanya berisi pembebasan dari berbagai aspek penindasan dan persamaan. Sebuah ajaran yang menyejukkan bagi komunitas yang selama ini termarginalkan dan tidak dimanusiakan, termasuk kaum perempuan. ${ }^{16}$ Bisa dikatakan Nabi Muhammad sendiri adalah seorang feminis, karena memperjuangkan hakhak perempuan atas ketimpangan sosial yang ada.

Secara garis besar gaung kebebasan yang dibawa oleh Nabi, ada yang bersifat perombakan total dan ada pula yang sifatnya evolutif. Perombakan secara total yaitu penghapusan bentuk tradisi yang tidak memanusiakan perempuan, seperti larangan mengubur bayi perempuan hidup-hidup, larangan menjadikan perempuan sebagai warisan, perempuan sekarang

\footnotetext{
13 Anggapan bahwa perempuan tidak pantas menjadi pemimpin keluarga memberi pemahaman bahwa tugas utama mereka adalah domestik. Sehingga semua pekerjaan rumah tangga, seperti memasak, mencuci, mengepel, memelihara anak menjadi tanggungjawab mereka semua. Mansoer Fakih, Analisis Gender dan Transformasi Sosial ..., h. 21.

${ }_{14}$ Dadang S. Anshori dkk, Membincang Feminisme: Refleksi Muslimah atas Peran Sosial Kaum Wanita (Bandung: Pustaka Hidayah, 1997), h.19

15 Annemarie Schimmel, Jiwaku adalah Wanita: Aspek Feminim dalam Spritualitas Islam terj. Rahmani Astuti (Bandung: Mizan, 1998), h. 92.

16 Nurun Najwah, Perempuan dalam Sejarah Awal Islam dalam Esensia: Jurnal Ilmu-Ilmu Ushuluddin (Yogyakarta: Fakultas Ushuluddin UIN Sunan Kalijaga, 2006, Vol. 7), h. 77.
} 
memiliki hak waris, perempuan tidak bisa dikawin cerai seenaknya, perempuan memiliki hak dan kewajiban yang sama di hadapan-Nya.

Adapun yang sifatnya evolutif yaitu perubahan yang dilakukan secara bertahap, adaptif, dan sifatnya kondisional seperti kadar warisan perempuan yang berbeda dengan laki-laki, kesaksian perempuan dianggap setengah dari kesaksian laki-laki, adanya 'iddah, nikah harus diwakilkan wali, saksi nikah tidak boleh perempuan, adanya hak ijbar, poligami, adanya hak talak pada laki-laki. Berbagai bentuk aturan tersebut untuk konteks masa kini masih menunjukkan adanya diskriminasi terhadap perempuan. Namun dalam konteks historis Nabi, kasus tersebut bisa dimaklumi karena sangat terkait dengan sosio-kultural masa itu yang mengharuskan perempuan diposisikan seperti itu. ${ }^{17}$ Menurut Amina Wadud al-Qur'an memang lebih sering menganjurkan reformasi gradual, sebab jika kebiasaan-kebiasaan tersebut dihapuskan secara masif justru akan menimbulkan masalah baru, makanya tetap dijalankan secara pelan-pelan mengikuti konteks perubahan itu terjadi. $^{18}$

\section{Mufassir dan budaya Patriarkal}

Jika Al-Qur'an dan hadis berbicara demikian, lantas mengapa justru beberapa persoalan ketidakadilan gender pada masa kini bersumber dari teks al-Qur'an dan hadis? Hal yang perlu disadari adalah produk pemahaman dan interpretasi al-Qur'an dan hadis pasti dipengaruhi oleh penafsirnya. Cara pandang penafsir juga terkadang dipengaruhi oleh tradisi ataupun konstruk sosial di mana dia hidup. Hal ini senada dengan jawaban Hamim Ilyas bahwa lebih dahulu harus dibedakan antara Islam orisinil, historis dan kultural. Islam orisinil adalah pengamalan Islam yang berkembang pada masa Nabi. Islam historis adalah tradisi yang berkembang di tengah masyarakat, terutama setalah wafatnya Nabi. Sedangkan Islam kultural dipahami sebagai penerjemahan nilai-nilai agama dalam kebudayaan maupun karya-karya dalam Islam. Feminis Islam sepakat bahwa ketidakadilan gender tidak muncul pada masa Islam orisinil. Ketidakadilan itu baru muncul pada Islam historis dan kultural. ${ }^{19}$ Oleh karena itu,

\footnotetext{
${ }^{17}$ Ibid., h. 80-85.

18 Amina Wadud, Quran Menurut Perempuan: Meluruskan Bias Gender dalam Tradisi Tafsir terj. Abdullah Ali (Jakarta: Serambi Ilmu Semesta, 2001), h. 147-148.

${ }^{19}$ Aksin Wijaya, Menggugat Otentisitas Wahyu Tuban: Kritik Atas Nalar Tafsir Gender (Yogyakarta: Magnum Pustaka Utama, 2011), h. XIV-XV.
} 
melakukan studi agama, terutama kajian atas teks al-Qur'an dan Hadis, perlu menggunakan pendekatan feminisme untuk mengembalikan semangat keadilan gender yang dulu telah diperjuangkan oleh Nabi. Dengan begitu agama bisa memberikan solusi baik atas problem gender yang muncul dari kesalahan interpretasi agama (internal) maupun ketidakadilan gender yang berbuah dari pola struktur budaya patriarkal masyarakat (eksternal).

Para mufassir klasik telah menggunakan ragam qira'at dalam menafsirkan al-Qur'an. Tetapi, kecenderungan penggunaan qira'at lebih dominan dalam penafsiran ayat-ayat hukum, teologi dan fiqih. Padahal dalam al-Qur'an isu relasi gender cukup banyak disebutkan dalam beberapa surah. Hal ini yang kurang dieksplorasi dalam kitab-kitab tafsir klasik. Oleh karenanya, pada sub-bagian selanjutnya akan membahas bagaimana pemahaman ayat relasi gender dengan melihat ragam qiraat yang melingkupinya.

\section{Peran Qira'at dalam Memahami Ayat Relasi Gender (An-Nisa', 4: 19)}

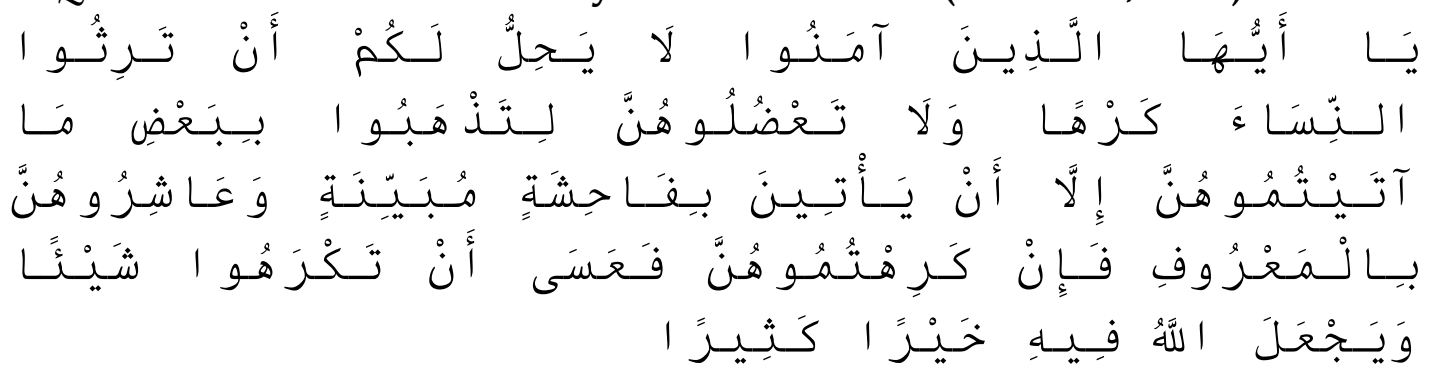

"Wahai orang-orang yang beriman! Tidak halal bagi kamu mewarisi perempuan dengan jalan paksa dan janganlah kamu menyusahkan mereka karena hendak mengambil kembali sebagian dari apa yang telah kamu berikan kepadanya, kecuali apabila mereka melakukan perbuatan keji yang nyata. Dan bergaullah dengan mereka dengan cara yang patut. Jika kamu tidak menyukai mereka, (maka bersabarlah) karena boleh jadi kamu tidak menyukai sesuatu, padahal Allah menjadikan kebaikan yang banyak padanya".

\section{a. Ragam Qira'at}

1. لَ يَسِحِلٌ 
Na'im bin Maisarah membaca (لا يحل) dengan huruf ta dengan taqdir-nya la tahillu lakum al-waras \atu. Adapun Imam yang lain membaca dengan huruf ya. ${ }^{20}$

2. كَرْْهَا

Ibn Kas \ir, Nafi', Abu 'Amru, Ibn 'Amir, 'As\}im, Abu Ja'far danYa'qum membaca dengan menfatahkan huruf kaf (كَرْهَ). Sedangkan H\{amzah, alKisa'i, Khalaf, al-H\{asan dan al-A'masy membaca dengan men-dhommah-

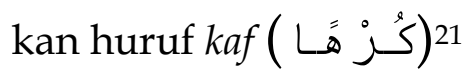

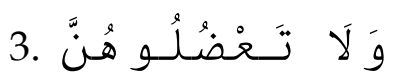

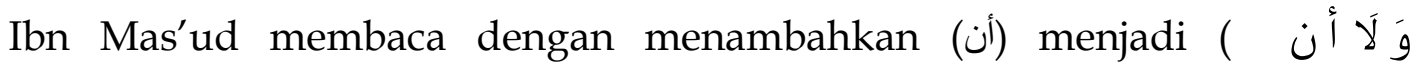

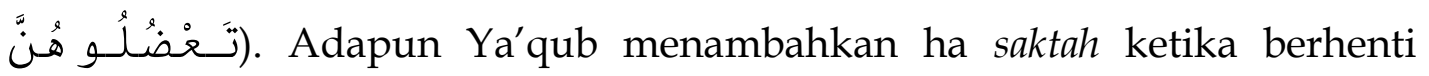

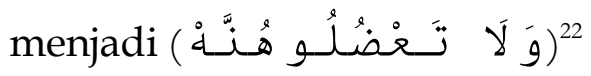

4. 1

Zaid Ibn 'Ali< membaca dengan men-d\}ammah-kan huruf ta dan men-kasrah-

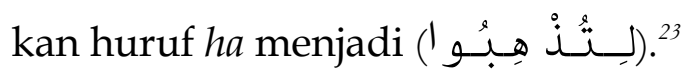

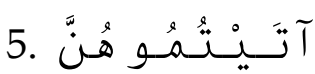

Ya'qub membaca dengan menambahkan huruf ha saktah pada saat berhenti. ${ }^{24}$

6.<smiles>[13CH][13CH3]</smiles>

Abu 'Amru, Abu Ja'far, Al-Asbihaniy, Warasy, al-Azraq dan al-Susi membaca dengan mengganti hamzah menjadi alif (يـا تـيـن (يـن). ${ }^{25}$

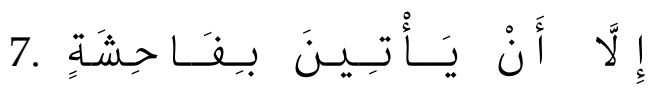
20 Abdul Latif al-Khatib, Mu'jam al-Qira'at, jilid 2 (Dimasqi: Dar Sa'd al-Din, 2000), h. 40.
${ }^{21}$ Abdul Latif al-Khatib, Mu'jam al-Qira'at (Dimasqi: Dar Sa'd al-Din, 2000, jilid 2), h. 40.
22 Ibid., ...h. 41.
${ }^{23}$ Ibid., ...h. 41.
${ }^{24}$ Ibid., ...h. 41.
25 Ibid., ...h. 41. 
Ubay bin Ka'ab membaca dengan (إلا أن يـنـشن علـيـمم). Adapun

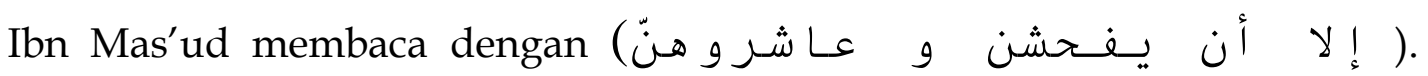
Bacaan ini juga bacaan Ibn 'Abbas dan 'Ikrimah. Namun Ibnu H\{ayyan mengomentari bahwa kedua bacaan ini bertentangan dengan mushaf Imam dan lebih condong kepada penafsiran atau penjelasan, bukan Al-Qur'an. ${ }^{26}$

8.

Nafi', Abu 'Amru, Ibn 'Amir, Hamzah, al-Kisa'i, Hafs 'an 'Asim, Abu Ja'far, Ya'qub membaca dengan meng-kasrah huruf ya atau mengikuti wazan isim fa'il dari "bayyana". Ibnu Kasir, Abu Bakar 'an 'Asim, al-asan, Ibn Muhaisin

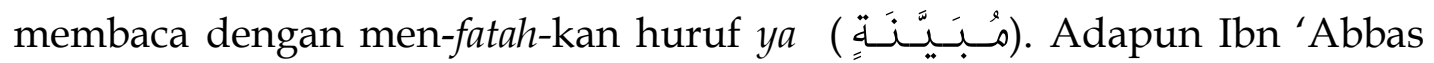

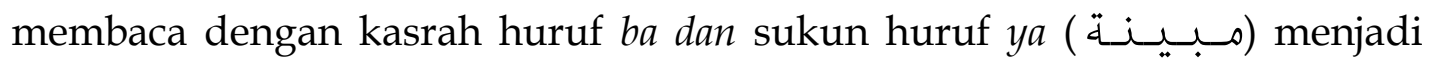
isim fa'il dari verba (أبــان ن). Ada riwayat juga dari Ibn 'Abbas membaca dengan bayyinah. Selain ragam di atas al-Kisa'i dan H\{amzah juga membaca

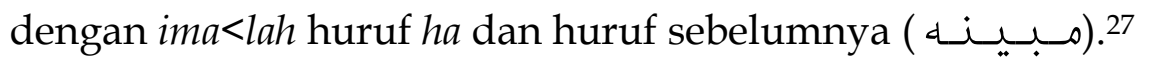

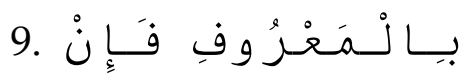

Abu "Amru dan Ya'qub dengan cara meng-idgham-kan huruf fa dengan fa setelahnya. ${ }^{28}$

10. فَحَسَسَى

Hamzah, al-Kisa'i dan Khalaf membacanya dengan imalah. ${ }^{29}$

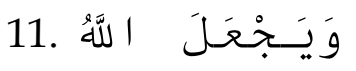

Imam Jumhur membaca dengan nasab sebagai 'ataf dari an takrahu. Adapun 'Isa ibn 'Umar membaca denfan me-rafa'-kan huruf lam dengan asumsi kalimatnya wa huwa yaj'alu. Adapun al-Zamakhsyari setuju jika diabca dengan rafa' karena posisinya sebagai hal. ${ }^{30}$

12.

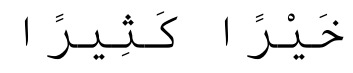

\footnotetext{
${ }^{26}$ Ibid., ...h. 41.

${ }^{27}$ Ibid., ....h. 42.

28 Ibid., ...h. 42.

${ }^{29}$ Ibid., ...h. 43.

30 Ibid., ...h. 43.
} 
Al-Azraq dan Warasy membaca huruf ra secara tarqiq pada keduanya. ${ }^{31}$

\section{b. Implikasi makna}

Di antara perbedaan qiraat dalam ayat di atas, ada dua kata kunci yang akan menjadi fokus kajian yang terkait relasi gender yaitu kata كـ هـ dan مـبـــــــــ

Ibn Manzur menjelaskan panjang lebar perbedaan antara kata al-kurhu dan al-karhu. Ia mengutip pendapat al-Farra' bahwa kata al-kurhu berarti masyaqqah (kesulitan atau kesukaran). ${ }^{32}$ Adapun arti kata al-karhu adalah ijbar, dengan pemaksaan. Ibnu Abbas dalam menafsirkan kata kurhan ditujukan kepada perbuatannya yang ingin memperdayai perempuan karena kebencian.

Kata karhan berasal dari kata o اكـر yang berarti sesuatu yang dipaksakan kepada seseorang untuk melakukannya. Penggunaan qiraat dengan kata karhan menunjukkan bahwa perempuan itu dipaksa agar mau dimiliki. ${ }^{33}$

Kedua, kata مينة bisa dibaca dengan mubayyinah atau mubayyanah. Kata mubayyinah adalah bentuk wazan isim fa'il dari verba bayyana. Adapun arti bayyana adalah tampak, jelas dan terang seperti kata tabayyana yang menunjukkan makna fi'il lazim. Al-Qasimi mengutip perkataan Abu al-Su'ud bahwa kata mubayyinah memiliki arti tampaknya prilaku keji tersebut lantaran, misalnya, karena istri nusyuz (membangkang), mencela suami dan keluarganya dengan ucapan yang tidak sopan, serta karakternya yang pemarah. Adapun kata mubayyanah merupakan ism maf'ul yang berarti bentuk muta'addi. Kata ini berarti jika ditampakkan, maka objek yang dimaksud adalah dijelaskan atau dibuktikan kondisi perbuatan keji itu dilakukan atau dengan menghadirkan empat saksi yang melihat peristiwa tersebut.

\section{c. Implikasi makna gender}

31 Ibid., ...h. 43.

32 Ibn al-Manzur, Lisan al-'Arabi, juz 5 ( Kairo: Dar al-Ma’arif,t.t), h. 3875.

33 Ali Fahrudin. Pengaruh Perbedaan Qira'at dalam Penafsiran Ayat-Ayat tentang Relasi Gender.Tesis UIN Syarif Hidayatullah. 2006. 


\section{Sرها Pertama, kata}

Ayat ini adalah larangan menjadikan perempuan sebagai barang warisan yang dapat dipindahtangankan dari ayah kepada anak atau dari anak kepada walinya. Menurut Ibn Abbas, dalam tradisi jahiliyah seseorang yang meninggal dunia dan meninggalkan istri lebih dari satu, maka walinya (yang laki-laki) lebih berhak dari pada orang tua perempuan. Jika mereka mengawini perempuan tersebut atau mereka menikahkannya dengan orang lain, sementara maharnya diambil walinya, atau yang lebih kejam lagi, perempuan tersebut ditahan dalam rumah walinya hingga meninggal dunia. Oleh karenanya, ketika Islam datang, perlakuan seperti ini dilarang dan dihapuskan.

Qiraah yang menggunakan fatah (كر ها) mengandung arti kebencian pada perempuan tersebut. Menurut Ibn Abbas, jika perempuan yang ditinggalkan itu tidak cantik, maka dia ditahan sampai meninggal dunia lalu hartanya diwarisi oleh walinya. Dalam penafsiran lain Ibn Adil berkata bahwa ayat ini berkenaan dengan seorang laki-laki yang memiliki istri yang sudah tua, sementara seleranya tertuju pada istri mudanya, lalu dia menahan dan menelantarkan istri tuanya. Dia tidak pernah menggaulinya sampai istri tuanya minta untuk diceraikan dengan memberikan tebusan padanya atau dia tetap menahannya hingga perempuan tersebut meninggal dunia, lalu dia dapat mewarisi hartanya. Ayat ini menganjurkan kepada suami untuk menceraikan istrinya, jika dia tidak mau menggaulinya dengan baik dan dilarang untuk mewarisi hartanya kerena kebencian kepadanya.

Kata yang berarti pemaksaan maupun kebencian ini bukan merupakan sebab haramnya perempuan dijadikan sebagai harta warisan, melainkan ditegaskan untuk menerangkan peristiwa yang terjadi pada masa itu. Pada masa tersebut, mereka mewarisi perempuan tanpa ridho dan sepengetahuannya. Jadi, tanpa sebab ada pemaksaan atau kebencian, prilaku ini tetap dilarang dalam agama Islam.

Melihat sebab turunnya ayat ini, setidaknya dapat disimpulkan dua hal. Pertama, larangan menjadikan perempuan sebagaimana harta warisan yang dapat dikuasai oleh ahli waris laki-laki dengan cara paksa. Penafsiran ini merupakan qiraah karhan. Kedua, larangan menelantarkan istri karena kebencian kepadanya lalu dia menunggu agar istri menggugat cerai dengan membayar tebusan atau membiarkannya sampai meninggal, sehingga ia 
mendapatkan harta warisan darinya. Ini merupakan penafsiran dari qira'ah kurhan. al-Qur'an diturunkan dengan ragam qira'attersebut untuk mempertegas bahwa motif apapun dibalik praktik mewariskan perempuan tidak dibenarkan sama sekali.

\section{Kedua, kata مبينة}

Menurut Ibn Kasir, ayat ini turun berkenaan dengan seorang laki-laki yang memiliki istri tetapi tidak ingin menggauli dengan baik, bahkan sering menyakitinya. Di sisi lain istrinya tersebut memiliki harta atau mahar yang dulu telah diberikan. Prilaku ini dilakukan agar mahar tersebut menjadi tebusan terhadap perlakuan buruk suami. Seorang suami menyakiti istri untuk meminta kembali sesuatu yang telah diberikan kepada istrinya, baik berupa mahar, uang belanja maupun harta lainnya.

Kata ta'duluhunna berasal dari fi'il madi "'addala" yang berarti menekan, mempersempit, mencegah, menghalangi, memukul menahan atau mempersulit. Dari pengertian ini, ayat ini ditujukan juga kepada setiap tindakan negatif negative suami terhadap istinya. Ayat ini tidak memperkenankan suami untuk menganiaya istri dengan maksud ingin menguasai hartanya.

Dari pemaparan di atas, qira'ah mubayyinah adalah prilaku yang jelas terlihat keburukannya, seperti nusyuz atau melecehkan suami. Adapun dengan qira'ah mubayyanah, perbuatan istri yang melakukan perbuatan menyimpang secara sembunyi-sembunyi sehingga perlu dibuktikan dengan menghadirkan saksi yang melihat atau bukti yang jelas. Dengan begitu, seorang suami tidak bisa semena-mena menuduh atau mengambil keputusan menceraikan istri tanpa bukti yang jelas.

\section{KESIMPULAN}

Dari penjelasan di atas dapat dipahami bahwa Ragam qira'at adalah bagian dari wahyu sehingga perlu diperhatikan ketika memahami ayat. Varian qira'at dapat membantu memahami kandungan ayat secara tematik dan kontekstual. Persoalan ketimpangan gender tidak terlepas dari pemahaman teks al-Qur'an yang dipandang tekstual serta keterpengaruhan konteks sosial-kultural penafsir. Oleh karena itu perlu meninjau ulang ayat gender dengan mempertimbangkan maksud al-Qur'an sejak pertama kali diturunkan. Pada akhirnya Perbedaan qira'at 
telah memberikan kontribusi untuk mengungkap dan memahami hal-hal yang ingin disuarakan oleh ayat-ayat relasi gender sebagaimana contoh pada Q.S. alNisa' (4): 19 di atas.

\section{DAFTAR PUSTAKA}

Anshori, Dadang S. dkk,. Membincang Feminisme: Refleksi Muslimah atas Peran Sosial Kaum Wanita. Bandung: Pustaka Hidayah. 1997.

Athaillah. Sejarah Al-Quran: Verifikasi tentang Otentisitas Al-Quran. Yogyakarta: Pustaka Pelajar. 2010.

Auda, Jasser. Maqasid al-Syari'ah as Philosophy of Islamic Law: A Systems Approach. London: The International Institute of Islamic Thought. 2007.

Connolly, Peter (ed.). Aneka Pendekatan Studi Agama, terj. Imam Khoiri. Yogyakarta: Lkis. 2011.

Fahrudin, Ali. Pengaruh Perbedaan Qira'at dalam Penafsiran Ayat-Ayat tentang Relasi Gender.Tesis UIN Syarif Hidayatullah. Tidak dipublikasikan.

Fakih, Mansoer. Analisis Gender dan Transformasi Sosial. Yogyakarta: Pustaka Pelajar. 2001.

Hidayatullah, Syarif. Teologi Feminisme Islam. Yogyakarta: Pustaka Pelajar. 2010.

al-Khatib, Abdul Latif. Mu'jam al-Qira'at. Dimasqi: Dar Sa'd al-Din. 2000.

al-Manzur, Ibn. Lisan al-'Arabi. Kairo: Dar al-Ma'arif.T.t.

Mustaqim, Abdul. Dinamika Sejarah Tafsir Al-Quran: Studi Aliran-Aliran Tafsir dari Periode Klasik, Pertengahan hingga Modern-Kontemporer. Yogyakarta: Adab Press. 2012.

Najwah, Nurun. Perempuan dalam Sejarah Awal Islam dalam Esensia: Jurnal Ilmu-Ilmu Ushuluddin. Yogyakarta: Fakultas Ushuluddin UIN Sunan Kalijaga. 2006.

Saeed, Abdullah. Interpreting the Quran towards a Contemporary Approach. New York: Routledge. 2006.

Schimmel, Annemarie. Jiwaku adalah Wanita: Aspek Feminim dalam Spritualitas Islam terj. Rahmani Astuti. Bandung: Mizan. 1998.

Shibab, Muhammad Quraish. Kaidah Tafsir . Tangerang: Lentera Hati. 2013.

Wadud, Amina. Quran Menurut Perempuan: Meluruskan Bias Gender dalam Tradisi Tafsir terj. Abdullah Ali. Jakarta: Serambi Ilmu Semesta. 2001.

Wijaya, Aksin. Menggugat Otentisitas Wahyu Tuhan: Kritik Atas Nalar Tafsir Gender. Yogyakarta: Magnum Pustaka Utama. 2011. 